\title{
Относно хъркането
}

\author{
Доц. Цоло Радолов Цолов \\ Катедра УНГ на МУ - София, \\ база УМБАЛ „Царица Йоанна-ИСУЛ“
}

\begin{abstract}
Резюме
Хъркането от векове ангажира човешкото внимание. То се възприема често като едно битово неудобство, нерядко довеждащо до разводи, нерядко обект на неприязън или насмешка. С напредването на науката се установяват и значителни отклонения във физиологията на дишането при хъркащия човек, установи се, че страда целият организъм. Всичко това доведе до прилагането на различни неоперативни и оперативни методики за неговото отстраняване, често без резултат поради непознаване добре на механизма на това явления. Авторът съобщава за своите интересни наблюдения над хъркашия човек, извършени за почти 40годишната си дейност като бронхоскопист.
\end{abstract}

\ ъркането се възприема най-вече като значително битово неудобство - интензитетьт му достига до 40-80 децибела (3). В същото време - то е проява на нарушение на дишането по време на сън и мнозина автори го свързват с т. нар. обструктивна сънна апнея. Все още се спори относно истинските механизми на хъркането и поради тази причина предлаганите многобройни оперативни и механични методи за отстраняването му не винаги имат успех (9).

На практика се касае за различни клинични фази на обструкция на горните дихателни пътища и основният симптом, който ги обединява, е хъркането $(2,3,4,7,12,16,17,26,27)$. В началната си фаза най-често се наблюдава като синдром на увеличено съпротивление на горните дихателни пътища, след това той може да прерасне в обструктивно понижаване на обичайната вентилация под $50 \%$ - т. нар. обструктивна сънна хипопнея и да достигне до синдрома на обструктивно спиране на дишането по време на сън, известен като синдром на обструктивна сънна апнея. Този феномен, хъркането, се среща доста често - докато до 30 годишна възраст само 20\% от мъжете хъркат и 5\% от жените, то над 60-годишна възраст хъркат над $60 \%$ от мъжете и $40 \%$ от жените (3).

Освен социалната страна, този проблем има и важно медицинско значение. Хъркането предизвиква многобройни краткотрайни пробуждания, накъсват се стадиите на съня, продължителността и дълбочината му, разстройва се архитектониката му $(3,4,17,22)$. Недоспиването е причина за много грешки, профе- 
сионален и битов травматизъм, интелектуална умора, промени в силата на паметта, настроението и поведението, немотивирани депресивни, емоционални и възбудни реакции, реактивна пулмонална и артериална хипертония, сърдечна аритмия, стенокардия, инфаркт на миокарда (18, $22,24,25)$. Установени са главните фактори, предизвикващи хъркането: намален тонус на мускулите на мекото небце, езика и фаринкса, различни обемни образувания (тонзили, аденоидни вегетации, кисти), изкривена носна преграда, „носна клапа“, вариетети в развитието на мекото небце и увулата $(2,3,4,13,16)$.

През своята дългогодишна дейност като специалист оториноларинголог и ендоскопист, авторьт е имал възможност да се убеди в горецитираното, но в същото време лично многократно е наблюдавал хъркане, свързано главно с епиглотиса. Такива съобщения в достъпната ни литература липсват, макар и мнозина автори теоретично да го допускат $(10,12,14,23)$.

От извършените от нас над 1264 фиброскопски интубации до момента установихме, че при 112 пациенти $(8,8 \%), 90 \%$ мъже, се наблюдава този феномен - хъркане, индицирано от епиглотиса. Затрудненията за стандартна интубация са били от класически характер, които се цитират в специалната литература, а именно: къса мускулеста шия (бича шия), ретрагнатия, големи предни резци и голяма горна челюст (еленови зъби), ограничена подвижност на темпоромандибуларната става, дълго и високо небце, съчетано с тясна уста, намалена или липсваща подвижност на цервикалния отдел на гръбначния стълб (нормална дефлексия 55 градуса) или в атланто-окципиталната и атланто-аксиалната стави, оростомия под 1,5 см $(1,8)$. Това са пациенти с различни заболявания, лекувани в хирургичните клиники на МУ - София и цялата страна. Общото при тях е това, че освен някои от горепосочените анатомични особености, никой от тях нямаше значително изкривяване на носната преграда, т.к. при всичките беше извършена ендоназално интубацията. След премедикацията с атропин - диазепам болните заспиваха и започваха да хъркат съвсем нормално и нерядко доста гръмогласно. Директна ларингоскопия с фиброскоп „Olympus“ ни показва, че при всички тях хъркането е било функция на епиглотиса, съчетано, разбира се, с някои от гореописаните анатомични особености на черепа $(1,5,6,8,20$,
МБ оториноларингология

23). След повдигането на епиглотиса с фибробронхоскопа, хъркането престава. Наблюдава се при два основни вида конфигурация на епиглотиса. При първата група пациенти епиглотисьт е омега-виден, дъльг, дълбоко разположен и при лежане по гръб пада назад, залепва се за задната фарингеална стена и дишането се осъществява през една цепнатина под формата на гръцката буква омега, формирана от короната на епиглотиса. Визуално се наблюдават струя мехурчета и слюнка, излитащи от тази цепнатина, синхронно със „звуковия съпровод“. При втората група пациенти, повечето принадлежащи към т. нар. „бича шия“", епиглотисьт обикновено е къс, плосък и широк и при заспиване по гръб пльтно ляга върху ларингеалната цепка и задната фарингеална стена. При тези пациенти е налице и голям месест език, който допълнително усложнява състоянието. При повдигане на епиглотиса с бронхоскопа и при двете групи пациенти хъркането се прекратява. При разговорите с близките роднини на пациентите се установява, че всички те наистина хъркат доста силно и нерядко спят в отделна стая.

Тези наши наблюдения определено доказват, че при част от пациентите хирургичното лечение на хъркането е неприложимо, защото да се коригира формата на епиглотиса е практически невъзможно и рискът не е оправдан. Все още остава въпросът при колко от хъркашите български граждани причината за това е епиглотисът? Ние го установяваме при $8,8 \%$ от извършените фиброскопски ендотрахеални интубации, които по принцип се извършват при пациенти, чиято конфигурация на главата и шията спада към различните анатомични вариетети или е гранична с условно патологични такива, но тази пациенти в живота си са граждани нормални, работещи и страдащи от хъркането не по-малко от всички останали. До сега никой още не е успял да установи процентът на тези хора реално в обществото и цитираните от нас проценти могат да се отнесат само към пациентите с трудна интубация, а не към всички хъркащи хора.

Желателно е, в случаите, когато пациентът и лекуващият го лекар стигнат до сьгласие за хирургично лечение на хъркането, да се направи една директна ларингоскопия с фиброскоп, която може да ни даде представа дали пластиката на мекото небце или носната преграда ще бъдат с очаквания ефект и дали те са основният 
субстрат на хъркането при дадения човек. Без съмнение, директната фиброларингоскопия е значително по-евтина, по-безопасна и бързо осъществима от една хирургична интервенция. Директната фиброларингоскопия ще подобри

\section{Литература}

1. Александров В., Б. Максимов: Анестезиология и реанимация, M., 1977, 4, 211-7.

2. Големанов В.: В „Затруднено носно дишане“, София, МФ, 1976, 31-37.

3. Йовчев Ил.: Автореферат, 1991, МУ-Пловдив.

4. Костянов С., Д. Илучев, Ил. Йовчев: ОРЛ страници, 1996, 3-4, $35-41$.

5. М. Милков. Диагностика на нарушенията на съня. Варна, ИК Стено, Международен бюлетин по ОРЛ, бр. 4, 2009 г., с. 31

6. М. Милков. Клинично обусловени нарушения на дишането по време на сън. Варна, ИК Стено, Международен бюлетин по ОРЛ, бр. 4, 2009 г., с. 37

7. М. Милков, Пл. Недев, Л. Матев, Ц. Тончев, И. Ценев. Лечение на съннообусловените нарушения на дишането чрез ендоназални и интраорални апарати. Варна, ИК Стено, Международен бюлетин по ОРЛ, бр. 4, 2010 г., с. 29

8. Пл. Недев, Г. Бояджиев, М. Милков. Видове интервенции при лечение на хъркане и обструктивна сънна апнея. Варна, ИК Стено, Международен бюлетин по ОРЛ, бр. 2, 2008 г., с. 47

9. Цолов Ц., Ст. Глогов: Оториноларингология, София, 1989, 1 , $1-5$.

10. Цоло Ц., Ст. Глогов: В: „Резюмета на IV Нац. конгрес по анестезиология, реанимация и интензивно лечение“, София, 16-18.09.1990, стр. 59

11. Braun LK: Mount Sinai J. Med.1994, 61, 95-186.

12. Cass N. and al.: Brit. Med. J., 1956, 1, 488-489.

13. Chabolle F., C. Sequert, B. Fleury, X. Lachiver, P. Carles, E. Salf, P. Naudo: Ann. Otolaryngol. Chir. Cervicofac., 1995, 98-106.

14. Chabolle F., X. Lachiver, B. Fleury, Marsot-Dupuch K.,Lacan St., Guily J., Meyer B., Chouard Ch.: Ann. Otolaryngol. Chir. Cervicofac., 1990, 106-128. прецизността при вземане на решение за хирургичното лечение на хъркането и ще намалеят случаите, когато при една извършена ,lege artis“ пластика установяваме, че хъркането не се е повлияло.
15. Chevalier D., Y. Robert, A. Mellart, J. Guien, J. Pigut: Ann. Otolaryngol. Chir. Cervicofac., 1994, 111, 393-396.

16. Chouard Ch., H. Valty, B. Meyer et all: Ann. Otolaryngol. Chir. Cervicofac., 1986, 103, 319-327.

17. Cistuli PA., CE. Sullivan: In „Sleep and Breathing“, New York, Marsel Dekker Inc., 1994, 405-447.

18. Deberry-Borowiecki B., A. Kunwa, R. Blanks: Arch. Otolaryngol., 1985, 111, 659-63.

19. Douglas NJ, O. Polo: Lancet, 1994, 344, 653-655.

20. Guilleminault C. and al.: Sleep, 1992,15, suppl., 13-16.

21. Gould GA and all: Am. Rv. Resp. Dis., 1988, 137, 895-898.

22. Hung L. and all: Lancet, 1991, 338, 1480-1484.

23. Kamani Y., L. Pandrand, A. Bougara: „105 congres francais ORL“, Paris, oct. 1998, Resumes des seances, p. 38.

24. Lavie P.: Chest, 1999, dec., 116 (6),1501-1503.

25. Lavie P., P. Herer, J. Zomer, N. Hadas: S. Sleep Res., 2000, 9 sup. $1: 112$.

26. McNamara SG and all: Thorax, 1993, 48, 754-764

27. O'Salivan R. and all: Am. J. Resp. Crit. Care Mes., 1995, 151, 194198.

28. Peppard PE., T. Young., M. Palta, Skatrud J.: N. Engl .J. Med., 2000, may, 11; 342(19), 1378-1384.

29. Pillar G., N. Peled, N. Katz, P. Lavie: J.sleep Res., 1994, dec; 3 (4), 241-244.

30. Saunders NA, Sullivan CE.: In „Sleep and Breathing“, New York, Marcel Dekker. Inc., 1994.

31. Stoohs R., Guilleminault C: J. Clin. Neurophysiol., 1990, 7, 83-92. 